\title{
Assessing the Role of Domestic Loans on Economic Growth in Cameroon
}

\author{
Dr. Kristine Joy S. Simpao*, Kum Raphael Tegha \\ Keimyung University, Daegu City, South Korea \\ *Corresponding Authors: Dr. Kristine Joy S. Simpao, Keimyung University, Daegu City, South Korea
}

\begin{abstract}
The main objective of the study is to assess the role of domestic loans given by financial institutions on economic growth in Cameroon from the period 1990-2019. That is investigating whether there is a correlation existing between domestic loans and GDP which is an indicator of economic growth. The study reveals that a change in domestic loans can bring a change in GDP everything been equal. The data for the study was collected from secondary sources. That is from world bank data base, several textbooks, articles and annual reports from IMF, world bank, and government. The time series data was analyzed statistically, using simple linear regression. At the end of this research work, treating and analyzing data using SPSS, it was revealed by the Pearson coefficient of correlation that domestic loans have a negative correlation on economic growth (GDP) of Cameroon. Meaning an inverse relationship between domestic loans and GDP. All in all, suggestions were given by the researcher that, because this work focused on the role of domestic loans on economic growth in Cameroon, a further research can be conducted on assessing the role of domestic loans given by micro financial institutions (MFI) on economic growth in Cameroon. Equally, future researchers can write on this same topic but using both coefficient of correlation and T-testing as methods of assessing role of domestic loans on GDP. Lastly, concerning programs, Cameroon government should set up "National Quality Award for excellence given by the president, introduce deferral of tax, reduce interest rate on loans during period of crisis, structural policies to help SME's and avoid embezzlement to improve correlation from negative to positive.
\end{abstract}

Keywords: Domestic loans, Economic growth, GDP, Financial institutions

\section{INTRODUCTION}

Financial institutions are enterprises that perform investments, grants loans, and accept deposits transactions. It supports commercial activity by providing financial resources that facilitate savings and investment to economic growth. These include commercial banks, central banks, and microfinancial institutions like credit Union, insurance companies, and others (Nyugab, 2016).

Generally, financial institutions redistribute funds among economic agents from those agents with the surplus fund to those who need these funds to either carry out consumption(C), Investment (I), Government expenditures (G), Export(X), or Import(M).

Some specific roles of a financial institution like commercial banks can contribute positively to Cameroon's economic growth. Such as loans given to customers generate interest to financial institutions, Firms invest from the loan and can make a profit, Household consumes from these loans obtained.

Also, financial institutions contribute to Cameroon economic growth by providing employment opportunities to Cameroonians and permit the government to raise revenue from taxes.

Therefore, the main objective of financial institutions in an economy is to provide long-term economic growth through the adequacy of the economy. Financing the economy is carried out through its source, capitalizing on the market, and debt financing banking market (Simion, Stanciu, Armaselu, 2015). In addition to roles financial institutions can perform as acceptance of deposits from economic agents, lending, agent of payment, advisers to investors, producing money. The central bank in collaboration with other financial institutions can contribute to economic growth using expansionary monetary policy using instruments like open market operation, minimum lending rate, special deposit, cash ratio, directives, moral suasion, funding, etc. So, injecting more money in circulation by financial 
institutions through its expansionary policy will increase investment, leading to economic growth but creating inflation. However, if financial institutions adopt a Contractionary monetary policy which will reduce money in circulation, it will reduce investment, GDP, and hence low economic growth.

Cameroon is in West Africa, and lies between longitude 80 and 160 of the Green Wish meridian and between latitude 20 and 130 North and South of the Equator ( Njabe Roland, 2000 ) Cameroon is triangular, bounded to the west by Nigeria, to the East by the Central African Republic, to the North by the Chad Republic and the South by the Republic of Equatorial Guinea, Gabon, Congo, and the Atlantic Ocean. Cameroon has a land surface area of 472,710 sqkm, with a population of approximately 28 million people. Cameroon has 10 regions with the capital Yaoundé. A governor heads each region. Cameroon has 240 ethnic groups and 24 languages (linguistic groups).

However, from an economic standpoint, Cameroon uses the Central African Franc (FCFA meaning Franc For French cooperation in Africa) as its sole currency. It is dependent on its primary agricultural products for exports. Some of these products include crude oil, petroleum, coffee, cocoa, rubber, banana, and timber. Her primary imports include machinery and transportation equipment, iron, and steel. Between 1961 and 1981, there was a positive balance of payment (BOP) for 8 years and adverse BOP for 12 years. Also, from an economic point of view, on the 12th of January 1994, Cameroon devalued her currency, and this made Cameroon's economic indicators have positive values.

The changes in FCFA parity to French Franc had brought the fluctuation of import and export of the country. Cameroon's economic growth for the first 20 years of independence turned around $7 \%$ with the liquidation and restructuring of most banks, coupled with the changes in the monetary and fiscal policies, internal and external components related to prudential ratios, sound banking management, Cameroon's sources of finance for the economybecame slow and squeezed. Currently Cameroon's economic growth stands at 3.8\%. Formal banking in Cameroon is ancient, in fact, less than 50 years old, and it traced the origin back to the late era of colonization. The first bank in Cameroon was established way before independence. However, before the advent of modern banks, small societies had some

sort of banking carried out in a primitive manner. The customs and traditions were regulating thrift and loan societies. Treasurers of such societies played all the essential functions of the bank.

However, the Cameroonian banking industry has changed from local practices to modern banking. Cameroon belongs to CEMAC (Economic and Monetary Community of Central African States), which is headed by BEAC (The Central Bank of Central African State). The banking system is regulated by bodies, which include COBAC (Central African Banking Commission), National Credit Council (NCC),Cameroon Association of Professional credit establishment( APECAM), BEAC, and MINEFI(Ministry of Economy and Finance). The advent of modern banking has seen the collapse, liquidation, and Recapitalization of individual banks such as the liquidation of bank meridian BIAO Cameroon (BMBC) in 1996 and credit Agricole du Cameroon (CAC) in 1997. The incorporation of the commercial bank of Cameroon and the Acquisition of Amity Bank by Atlantic Bank and the Progression National Financial Credit Company) NFCC) to National Financial Credit Bank (NFC Bank) in 2006. However, with the current prudential ratio and strict regulations.

At least 15 commercial banks are operating in Cameroon today, and they include;

$>$ Societégeneral des Banque au Cameroon (SGBC)

$>$ SCB-CreditLyonais du Cameroon (SCB-CL)

$>$ Atlantic Bank

$>$ Citibank

$>$ Ecobank

$>$ Union Bank of Cameroon (UBC)

$>$ Afriland First Bank PLC

$>$ National Financial Credit Bank (NFC Bank

$>$ Union Bank of Africa 
$>$ Banque International du Cameroun pour l'epagne et le credit (BICEC

> Commercial bank of Cameroon, Community Credit of Africa (CCA) and others.

Apart from Atlantic bank PLC, Afriland First Bank, Union Bank of Cameroon, Ecobank, Citi bank, Standard Chartered Bank, NFC bank, and Union Bank of Africa, the other banks have government share-holdings of which shared dividend between shareholders and government. Financial institutions that consist of commercial banks and another micro-financial institution can help to bring sustainable economic growth by financing the economy (granting Loan), accepting deposits from economic agents, provide employment, raise revenue for the government from taxes.

\subsection{Statement of the Problem}

According to the New approach to ordinary Level economics, a commercial bank is a profit-making privately-owned financial institution that receives deposits from the general public, safeguards them, and makes loans to the public. Some other functions of commercial banks are; providing investment advice to the public, gives advice to the customers on financial markets, provides foreign exchange services, and issuing travel cheque to customers. They also act as guarantors; they carry many other roles such as agency role, payment role, policy role, and risk management role. These services carried out by commercial banks go a long way to raise income levels and standards of living of citizens. Financial institutions are generally institutions that deal with money. That is commercial banks, central banks, and microfinance like credit unions.

Inthe mid-1980s, Cameroon faced a severe economic crisis, which was very detrimental to every sector of the economy to which financial institutions were involved. Various conditions combined to lead to this crisis. The government affirmed that the crisis was an immediate cause of a drop in prices of imports in the international market. The most severe outcome was the increase in the prices of daily commodities.

Following the economic crisis, the Cameroon government introduced a reform program that focused on re-organizing the public finance system, liberalizing foreign trade, which led to economic recovery in the late 1990s still to solve the economic crisis. The introduction of the Structural Adjustment Program (SAP) in Cameroon meant that some economic policy carried out the changes. Popular opinion holds that the SAP had failed because of the level of poverty increased dramatically during the late 1980s and 1990s. The admission of the HIPC debt reduction initiative in April 2006 brought Cameroon to a critical development goal. With the attainment of the HIPC (Heavily Indebted Poor Countries) completion point, Cameroon exports a lump sum of financial resources of more than 1400billion FCFA. These funds were free and was out to achieve a sustainable improvement in living conditions as well as a significant reduction in poverty, completed in January 2000. Since 1990, the selling of last state-owned banks created new regulations, world financial crisis also emerged in 2008.Again from October 2016 to present date (2020) another political crisis and Covid- 19 which all these series of crisis affect activities of financial institutions and economic growth in Cameroon.

This research study was conducted toassess the extent to which domestic loans given by financial institutions can affect economic growth in Cameroon.

Specifically, the following sub-questions are about to answer:

1. What trends exist between real GDP rate and domestic loans rate provided by financial institutions within 30years?

2. What is the correlation between domestic loans provided by financial institutions and real GDP?

3. What are the issues and concern of financial institutions in Cameroon that affect its contributions to economy?

4. What programs or measures should Cameroon government in collaboration with financial institutions take to improve the domestic loans contribution to economic growth?

\section{Hypothesis}

Ho: There is significant relationship existing between domestic loans and GDP

\subsection{Theoretical Framework}

The role of financial institutions in economic development has been extensively documented. Government policies had encouraged different sectors in the economy to provide highly subsidized 
financial aid to mobilize economic activities. The study is anchored by Muhammad Saqib Khan, et.al., (2015) article on The Role of Financial Institutions and the Economic Growth: A Literature review, which has been adapted by researchers and financial institutions and highlights the contributions of financial institutions in country's financial development. The paper noted the policymaker's and economists generally agree that financial institutions such as commercial and investment banks, bond and stock exchanges can lead to economic growth. Muhammad mentioned the determinants of financial development base on the summarized literature such as GDP, M2 (Money and close substitute), savings, deposits, exports/imports.

In addition with Muhammad theory, Nikolas Dritsakis and AntoniosAdamopoulus (2010) affirms that there's a causal relationship between financial development and economic growth.However, Rati Ram theory mentioned that there is an empirical evidence that financial development promotes economic growth. With these arguments, researcher wants to identify the impacts of domestic loans on economic growth in Cameroon.

\subsection{Economic Growth Theories}

There are several theories that review economic growth, considering that the researcher's topic is related to economic growth and considering that different schools of thoughts exist because of different ideas, the following theories constitute the theoretical framework of this work. These are WW Rostows' 5stages of economic growth, Neoclassical model, Endogenous growth model and Keynesian theories(John, 1936).

First, the WW Rostow 5 stages of economic growth. According to Ray as observed in (Ray et al., 1994) WW Rostow postulated that for a country to achieve economic growth, it must pass through five stages which include: The traditional society stage, Precondition for taking offstage, Take-off stage, Drive to maturity, the stage of high mass consumption.

Second, following Campbell R. et al. (1993), the neoclassical growth model was introduced principally by Robert Solow. This model explains economic growth, considering the virtue of capital accumulation, population growth. Solow makes use of two components, the long-run capital-output ratio, and the per capita growth curve. According to the first component, the long-run capital-output ratio, if both output and capital are growing at the same rate. Whatever that rate might be, the capitaloutput ratio remains the same. The long-run equilibrium capital-output ratio increased by a higher saving rate and decreased by a higher growth rate of output. If output growth and saving rate are stable, sothen the long-run capital ratio remain the same. The second component of the neoclassical growth model of Solow is the per capita growth curve. These curves show how the growth rate per capita GDP depends on the capital-output ratio holding other factors constant.

Third is the endogenous growth theory. According to Ray et al. (1997), the stipulated theory of Joseph Schumpeter, the reason why it was called the Neo-Schumpeterian model. The neoclassical model of Solow did not explain the rate of technical progress. Solow took the rate of technical progress to be something that "just happens." In contrast to Solow, Schumpeter believed that more unsatisfied human wants and better products, therefore, research and development are carried out to make a profit on new and better products, thus resulting in economic growth. Unlike neoclassical growth theory, in the endogenous growth theory, a higher saving rate can cause enormous, long-run growth through stimulating more invention. If, for example, companies operate with high powered computers, discoveries become relatively cheaper, and the rate of technological progress increases. The Schumpeterian view was supported by an economic historian, JacobSchookler, who found out that profit was the prime motive in the historical record of essential inventions in petroleum refinery, railway, and farming.

Lastly, is the Keynesian theory. Karl et al. (1994), the Keynesian growth rate model and theories of Sir RayHarrod of Britain and EvseyDomar in the United States dominated the economic literature for a generation after world war 2. Following the early model of Harrod, economic growth needs three main variables which include The economy's saving rate (percentage of national income devoted to saving), Capital and output ratio (the amount of additional capital model for one unit of output increase), and economic growth. Following Harrod, Economic growth given formula is as a Saving rate /capital-output ratio. 


\subsection{Conceptual Framework}

To realize the purpose of the study, the researcher utilized the Systems theory which is an interdisciplinary field of science and the study of nature of complex systems in nature, society, and science. More specifically, it is a framework by which one can analyse and/or describe any group of objects that work in concept to produce some results. The researcher philosophy about his work is that "everything been equal when domestic credit change, it can bring a change in GDP (economic growth) either negatively or positively" and vice versa. The diagram is as follows:

Independent Variable

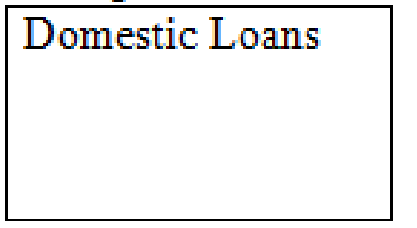

\section{Dependent Variable}

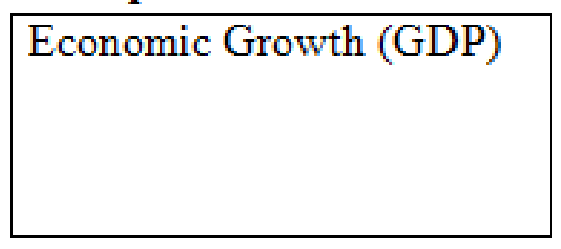

Figure1.0. Conceptual framework of the study

\section{REVIEW OF RELATED LITERATURE}

\subsection{Financial Institutions Concept}

Financial institutions perform important functions in development processes and the economic performance of financial markets. Research on the role of financial development in growth can be traced back at least to Schumpeter (1912), who pointed out the role of a country's banking system in that country's economic development. The inherent functions of financial systems, including savings to their highest valued use, obtaining information, evaluating and monitoring investment projects, and enabling individuals to diversify risk, have been widely believed to encourage productive investment and therefore total factor productivity and economic growth (Huang, 2005, p.6). There is a large agreement on the positive effects of financial development on economic development. In addition, making a stable and powerful financial system is important to reduce the negative effects of financial crises in countries' economies. Consequently, a better understanding of the sources of financial institution is needed in order to put good policies that encourage financial development. Research in this area has traditionally underlined the macroeconomic (e.g., inflation, income level, saving rate), institutional and geographic factors that determine financial development.

In recent years, there has been a growing emphasis on the institutional factors in the literature. The word "institution" has been defined by Douglas North (1991) as humanly devised constraints that structure political, economic and social interaction. They consist of both informal constraints (sanctions, taboos, customs, traditions, trust, social capital, and codes of conduct) and formal rules (constitutions, laws, property rights). Throughout history, institutions have been devised by human beings to create order and reduce uncertainty in exchange. Institutions act like the engine of an economy; as that structure evolves, it shapes the direction of economic change towards growth, stagnation, or decline (North, 1991, p.97). Operating under such a large definition, the relationship between institutional quality and economic performance has been investigated by economists since Adam Smith, who have tried to answer the question of which institutions stimulate economic development under different socio-economic conditions.

Most of the empirical research on the topic provides evidence confirming the important effect of institutional quality on economic performance (e.g., Knack and Keefer, 1995; Mauro, 1995; Hall and Jones, 1999). In particular, research by Easterly and Levine (2003) and Rodrik et al. (2004) highlights the dominant role of institutions over those of geography and policy. They argue that geography and policy affect economic development through institutions by influencing their quality, and the direct Policies and regulations are often important elements of a larger institutional equilibrium. Hence, changing them is not always a simple and risk-free task, and addressing the question of what determines the emergence of "good" institutions - i.e., institutions that promote financial development - seems particularly important (Fergusson, 2006, p.30). Good institutions promoting financial development transfer sources of savings to productive areas effectively. As in all markets, the functioning of financial markets is affected by asymmetric nature of information, and related problems (adverse selection and moral hazard). For example, in adverse selection, people who want to 
borrow may hide some of their negative features that might stop this activity. In this way, they can obtain the requested funds with low cost and without a risk premium. In this case, creditors give loans at a higher cost corresponding to the probability of hidden information by demanding a risk premium or by reducing money that they put on the market. Since well-qualified people who want to borrow cannot be distinguished from the others, they are affected negatively by such a situation.

In general, people who want to borrow cannot find funds or have to put up with higher costs because, under such a situation, their information cannot be trusted by the lender. This situation can prevent well-qualified borrowers from borrowing from the market. Thereby, the proportion of borrowers with negative features will increase in the market. Consequently, it became probable that the flow of fund suppliers' money shifted towards risky borrowers more than reputable customers. In other words, the possibility of adverse selection will increase.

The other problem that can come from the asymmetric information is a moral hazard. Such a hazard may emerge from careless or inappropriate attitude that goes against the contract rules. For example, borrowers may be inclined to employ their funds in risky business ventures due to expectations of higher income. However, this choice increases the repayment risk. The borrowers' normal or risky business decisions affect the lenders' risk, but not their earnings. Therefore, creditors prefer to provide funds to normal-risk investments. In this case, as with adverse selection, lenders may be reluctant to provide funds due to a lack of confidence in borrowers. Increasing funding costs lead high-risk investors who pursue higher profits to remain in the market and deter normal-risk investors from entering the market.

Consequently, the financial markets that suffer from the problems of adverse selection and/or moral hazard due to a situation of asymmetric information will move away from the equilibrium. If asymmetric information is not prevented, agents with excess savings will hold their cash instead of taking unpredictable risks. Institutional quality and the legal framework are likely to affect financial development through the ability of the financial sector to channel resources to finance productive activities. In the absence of an adequate regulatory organ and supervision, the ability of financial markets to redistribute funds may be strongly undermined by lack of depositors' confidence. This will shift funds abroad and generally away from viable domestic investment opportunities (Grigorian and Martinez, 2000, p.5; Law and Azman-Saini, 2008, p. 1-2).

The major events or problems financial institutions are facing or had faced from 1990-2019 are the economic crisis of the late 1980s and effects felt from 1990-1994, accepted into HIPC initiative in 2006, the world financial crisis of 2008, the political crisis of 2016-2020, Covid 19 of 2019 till present and high-interest rate levied on loans that are not even reproductive but for consumption and finance of war (deadweight debt). In all these statements of problems can affect domestic credit and GDP (economic growth) of Cameroon

\subsection{Role of Financial Institution in Economy}

ShaikatMozumder in his article role of financial institutes in financial market summarized the role of financial institutes in Bangladesh economy. The author said there are three different flows of funds from surplus units to deficit units. One set of flows represent deposit from surplus units that are transformed by depository institutions into loans for deficit unit. The second set of flows represent purchases of securities issued by companies that are transformed into finance company loans to deficit units. The third set of flows reflects the purchase of shares issued by mutual funds. The article ended saying deficits units also receive funding, from insurance companies and pension funds, since insurance companies and pension funds can purchase massive number of stocks and bonds

Syed MohsinRizvi (2002) defined financial institution as an establishment that conducts financial transactions such as investments, loans and deposits. Examples of such institutions according to him were commercial banks, investment banks, brokerage bank, insurance companies, mortgage, investment company. He said the primary role of financial institutions in an economy is to provide liquidity to the economy and permit a higher level of economic activity than would otherwise be possible.

According to the Brookings Institute, banks accomplish this in three main ways: offering credit, managing markets and pooling risk among consumers. The investment portion is heavily influenced by financial institutions, as they facilitate how much people save and invest in an economy, which is a 
cause for economic growth. Without financial institutions, people wouldn't be able to take advantage of rising and falling interest rates and there would be no saving of money

Project manager of India Brand EquityRanjanaBisht(2019), said there are different importance that financial institutions could performed, that is provide economic loans to people and organization, provide financial interest to money kept as deposit account and that financial institutions can control and manipulate the money flow in an economic market.

\subsection{Economic Growth}

Kael.E et al. (1994), Economic growth refers to an increase in the output of an economy. According to them, economic growth occurs when Society acquires more resources Society discovers ways of using the available resources more efficiently. J.L Hanson (Economic and commercial Dictionary), defined Economic growth as an increase in the per capita income or increase in the GDP. From the recent literature, the term refers to a sustained increase in the country's output of goods and services to be more precise. In terms of GNP, economics is the product per capita output, which is generally measured. The improved economic production growth is due to the development of production, which involves producing more goods and services with the same economic resources as capital, labour, just to name few.

According to Campbell. $\mathrm{R}$.et al (1993), Economic growth is the outward shift of the production possibility frontier (PPF), here PPF refers to a curve that shows the maximum combination of 2 goods that can produce using the available resources at a particular time.

Paul Romer, Nobel Laureate (Romer, 2018), from the Concise Encyclopaedia of Economics, considered economic growth as a situation when people resources and rearrange them in more valuable ways.

\subsection{Indicators of Economic Growth}

Concerning indicators of economic growth, different articles or authors had used different indicators to measure economic growth.

Christine Mai Tran (Feb 2011 Australia) said indicators of economic growth between 1970-2005 were real GDP per capita, physical capital expenditures per capita, inflation growth rate, research and development expenditures per capita. All these indicators according to the reporter must be adjusted with the level of population during the period, reason why all these ends with per capita.

More so, Lawn (2008) and Lee et al.(1994b) said that the indicators used to measure economic growth are real GDP per capita and GPI. According to the reporter using annual real GDP per capita with data collected from the world bank, it could provide accurate representation on how economic growth change over time as population also changes.

Furthermore, (Jackson \&Mclver 2001) and Stern (1991) said on their papers that indicators that can be used to measure economic growth are GDP or real GDP per capita that occur considering a long period of time. According to them economic growth is changing from the supply side, such as the accumulation of physical capital, the progress of skills, ideas, innovation, population growth and how factors of production are used, combined, and managed.

Foreign Direct Investment is an important indicator that shows the confidence of foreign investors in the economic, political and security stability of a country. An empirical study that was conducted by Rah man and Salahuddin considered empirical data in Pakistan from 1971-2006 shows a positive relationship between foreign direct investment and economic growth. This indicates that foreign direct investment promotes economic activity and improves quality of human capital spillover effects. Foreign direct investment promotes economic growth through high technology transferred, efficiency, improvement in the quality of production factors and enhances production leading to high GDP.

ZeljkoLovrincevic et al (2013) investigated whether GDP is an appropriate indicator of sustainable economic development. The System of National Account (SNA 1993) that collected data defined GDP as an overall indicator of economic growth.

As if that is not enough, Sweigkhalid and Sabri et al (2018) researched on the impact of investment on economic growth using Palestinian national income and GDP. These researchers used GDP as key indicator to measure economic growth. 
Gabi El-Khoury (2015), using national account statistics of the Arab countries selected indicators of economic growth were used. One of the indicators used to assess economic performance in Arab countries and worldwide was GDP. Tables that consisted of data collected were nominal GDP, real GDP rate, GDP per capita

\subsection{Role of Financial institutions on Economic Growth}

In a similar topic like the role of financial development in the economic growth of Central Eastern and South Eastern Europe (CESEE) was written by four persons, they were Paola Bongini, MalgorzataIwanicz D, PawelSmaga and BartoszWitkowski. This study focuses on CESEE countries in the post-communist era from 1995 to 2014 which coincided with the opening up of financial markets to foreign investors and global financial crisis. Authors of this article investigated that whether economic growth in CESEE countries has benefited from the presence of foreign -owned banks. At the end they introduced some refined measures of financial development and control for banks' financial strength, like privatization of state-owned banks and enterprises, liberalisation of market entry for private investors both domestic and foreign. These authors traced the potential role of foreign banks using two measures, that is decomposition of domestic credit to the private sector (as a ratio of GDP) and the ratio of foreign-owned bank lending to total domestic credit.

The methodology and data used by these authors, GDP and GDP per capita were considered as dependent variables and many independent variables used by three group of measures, that is macroeconomics, institutional and financial system development. Finally after testing result using estimationin multiple regression models on three measures, results did not show complete unanimity , the bulk of empirical research on the mechanisms through which finance affect growth suggested that countries with higher ratio of credit to the private sector to GDP and a higher market capitalisation to GDP grew faster.Moreover, this article challenges the idea that foreign-owned banks are a source of innovation with positive spill-over effects in local banking markets. Finally, these researchers found that bank credit could be an important source of economic growth to the extent that development banks are involved in the process of providing loans to the private sector.

Correlation analysis between structure of financial system and economic growth in Romania (Procedia Economics and finance 32(2015) 1332-1341) equally focused on examining the correlation between the structure of financial system and economic growth. The article considered set of data for a period of 19years, that is between 1994-2012 obtained from Bucharest Stock Exchange, National Bank of Romania and the world bank. Using quantitative methodology, correlation analysis and multiple regression models, GDP was considered as dependent variable and three independent variables like domestic credit, loans rate, average annual growth of broad money(M2). These authors of the written article after solving the multiple regression model, using the above-mentioned variables and SPSS (Statistical Package for the social science), it was found out that a perfect direct relationship between variables. Testing the significance of the correlation coefficient was carried out using t-test.

Bakar Hamad Omar, SulongZ (2018) on his article wrote on a similar topic, role of financial sector on economic growth described the discussions from into four categories in order to capture the discussions on the results provided from various researches. Sample of studies into diverse time frames was taken into consideration to ensure the mixture of ideas and results. The article divided these discussions into four main sections, first and second sections described by considering the effect of financial sector whether it is positive or negative. Third part described the effects of financial sector to higher income and lower income countries. Fourth part explained the transmission channels of financial sector on economic growth. Further subsections to each part were explained within the articles. Results, implications, and discussion were presented at each category. It seems that, the effects of financial development on economic growth is subject to selection of time frames selected, However, in most cases it seems that the impact of financial sector is more significant and positive to the developing countries compared to developed countries. Given the recently development of methodologies in terms of econometrics methods and use of proxy such as Financial index, it will help to determine the effect of financial sector on economic growth in more advanced way, rather than concentrating on past methodologies and proxy.

In past years, a number of researchers have written about economic growth and financial institutions of which commercial banks are inclusive. This research focuses on the three selected studies to survey 
the present sample of literature review relating to economic growth. Neba Cynthia(2008) carried out a study on assessing the role of microfinance institutions(MFIs) in the growth of Cameroon's economy. One of the main reasons for this study was to help government and other agents involved in the growth of the economy to develop an excellent developmental strategy and policies. The work intends to help micro-financial institutions to improve on their services or to implement advanced measures to enhance economic growth in the economy. She made use of time-series experiment design in the collected data on two variables, loans provided by microfinance institutions and GDP per capita from 1996 to 2007. Loans provided by MFI the independent variable, while GDP was the dependent variable. Using both descriptive methods of data analysis, median, standard deviation, and inferential tools of data analysis such as the F-test, R2, t-test. Durbin-Watson statistics tests the hypothesis, which shows that 'there is no relationship between loans given to the economy by MFIs and the GDP per capital' she concluded that credit granted by MFIs has a significant effect on the growth of the GDP per capita. Hence, she rejected her null hypothesis.

NGU (2007), wrote in his work that banks in Cameroon have a positive and significant contribution to the growth and development of the economy. Firstly, credit yields interest for the banks, and secondly, the banks have provided employment, increase government revenue through the taxes they pay.

Nkeng (1960) writing on financial institutions, in general, stated that they have not been doing enough to sensitize their customers and would-be customers on what is required of them to benefit from the facilities offered them entirely. He proposed the expansion of the agricultural sectors of the economy, which will, in turn, promote economic growth and development.

Marius Nibalkome( 2011) wrote on assessing the role of commercial banks on economic growth in Cameroon. The study shows how Loans affect GDP and, consequently, economic growth. The secondary data and quantitative research reveal that loans from commercial banks have positive impacts on economic growth. Recommendations were given for future researchers to assess the role of financial institutions on economic growth.

\subsection{Controversial Contribution of Financial Institutions to Economic Growth by Different Authors.}

There is a lot of disparity or controversy in the method and empirical results used by different authors to measure the contribution of financial institutions to economic growth. Below is a table showing a summary of differences and similarities between literature reviews on those authors written on the contribution of financial institutions to economic growth or related topics

Table1. Different authors with similar or controversial methods, and results on related topics

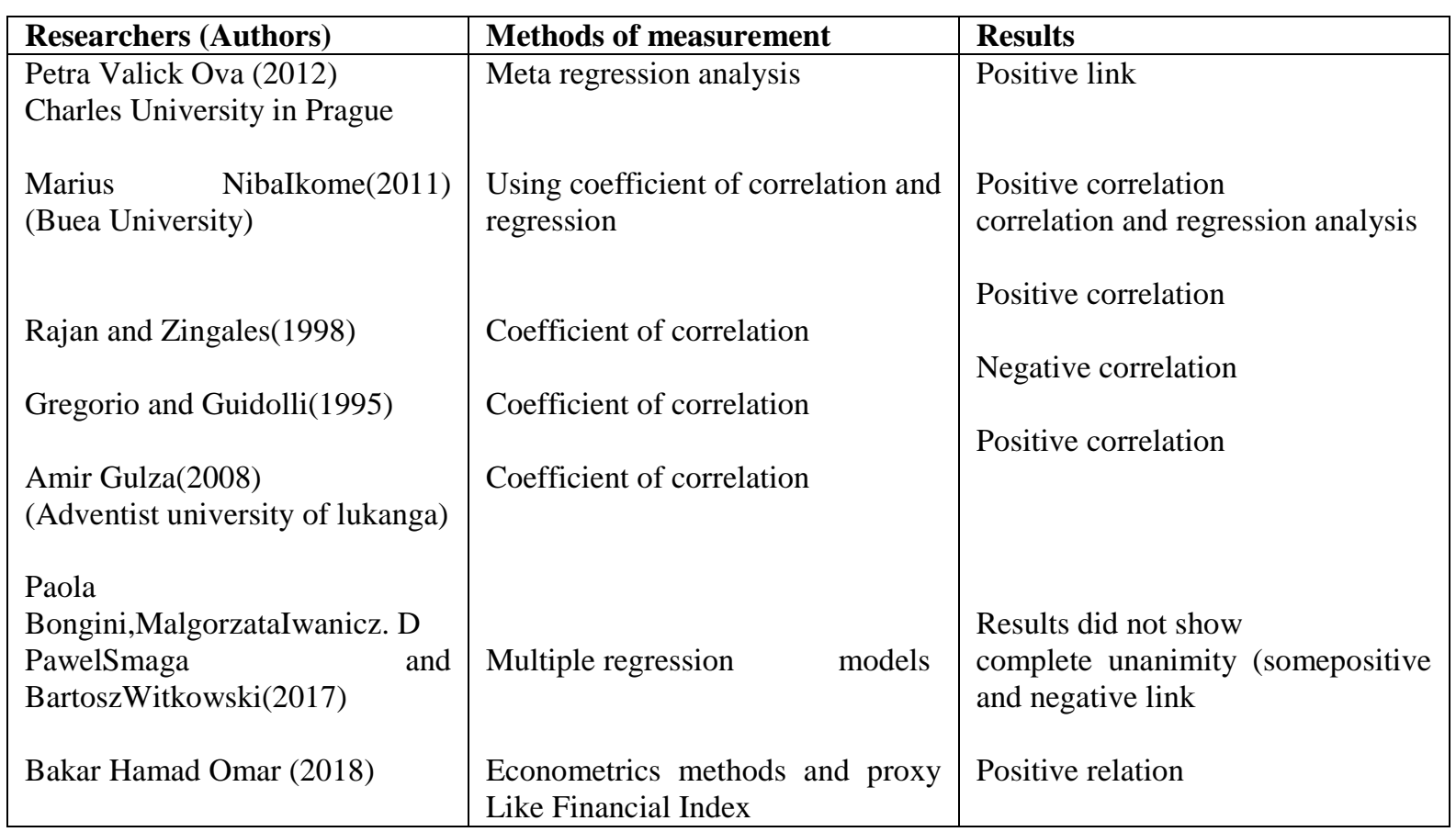




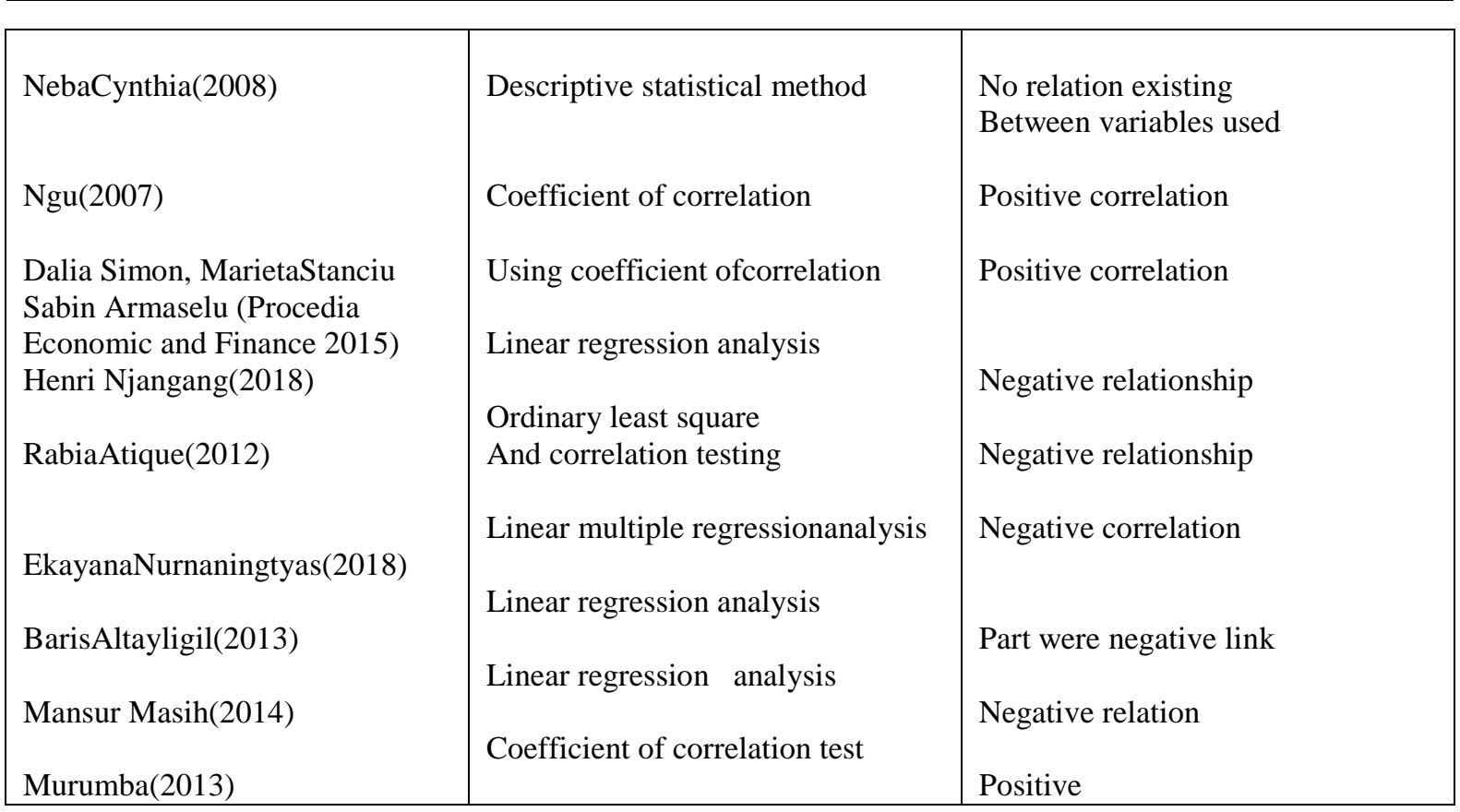

The table above shows the summary (synthesis) of literature review indicating differences and similarities among researchers who have written on similar or related topic and their controversial results obtained.

\subsection{Improving Loan System Services Evidence from World Financial Institutions}

Journal Grossarchive.com reported on a topic loan syndication as an alternative business financing strategy in Nigeria, a case study on the Union Bank of Nigeria

Lack of fund has been one of the major problems against the progress and growth of our business organization. This is caused by factors such as low saving(vicious cycle of poverty), ignorance of the public to invest and mismanagement. The article revealed that there are many ways to solve these problems of finance and providing adequate finance to Nigerian's organization such as equity, stocks, retained profit, savings, but for the purpose of this paper attention was given to loan syndication.

This article focused on the appraisal of the methods and ways through which Union Bank of Nigeria plc can get funds through loans from a group of financial institutions such as commercial banks, merchant banks, insurance companies, development banks and financial institution like government thrift and loans societies. It equally focused on the different classes of loan that is longterm loan, medium term loans and short-term loans. The categories of loan provided by the different types of financial institutions listed above could be considered by Union Bank of Nigeria plc before using loans as a source of finance, rather than other sources.

Another strategy the paper considered was factors considered by consortium of financial institutions before giving out loans to business organization. The securities and interest rate acceptable by the consortium were equally considered by the paper. Furthermore, reasons why some financial institutions don't go into loan syndication was answered by this article. The importance to study how the interest of the consortium is protected in the Union Bank of Nigeria as well as how the interest of each member of the consortium is protected within the group was discussed by the researcher. From these above-mentioned strategies given by the article, Union Bank of Nigeria plc chooses to finance their projects and specifically loan syndication implemented, everyone will feel and enjoy these strategies.

Furthermore, in an article written and published as Ukessay (2018), the topic Customers Relationship Management in Indian banking sector, the researcher acknowledged that the advent of financial crisis has forced organisations to restructure themselves in order to survive and grow. The restructuring process have brought about the emergence of the" new paradigm" which the researcher called Customers Relationship Management (CRM). Customers Relationship Management is a business strategy that the Indian Bank is using to maintain one to one relationship in today's world, it equally 
important for all institutions to maintain rich and fruitful relationship.CRM is a business strategy that integrate people processes and technology to maximize the relationship existing between organisations and all types of customers. Using CRM, it helps the organisations to understand the customer better which enable organisations to effectively customize their products and service offering according to customer's needs, in order to retain customer's loyalty and satisfaction. Many organisations like the bank of Indian used CRM strategies to make revenues and high profits.

Therefore, for many financial institution to develop customer's retention strategies, they should create relationship managers for select customers, airlines have frequently flyers program to reward loyal customers, credit card offers redeemable bonus points for increased card usage, telecom services operators provide customized services to their heavy users and hotels have personalised services for their visitors. This article revealed that for an organisation to effectively succeed in CRM strategies, it should identify or considers important factors like promote customer oriented philosophy, adopt customers based measures, develop end to end processes to serve customer's support, handle customers complaints, track all aspects of sales create "holistic" view of customers sales and service information .However, a sustainable CRM strategies will depend on how well an institution attract and retains a large customers base.

The following are some best practices grouped under three different continents that can improve domestic loans contribution toward GDP. That is Europe, USA and Africa best practices that are used to improve the correlation between these variables.

Firstly, European continent is using transformative credit life cycle management solution that digitalizes and automate every step of the credit process (credit lens solution). This tool transforms credit process and eliminate time consumption, redundant work, and more experience for customers across Europe.

Apart from the strategy above, banks in Europe provide financial services that meet the specialized needs of SME's while coping with the high risks and costs associated in servicing transactions. As if that is not enough, European government is reducing the asymmetrical information of SME's and high perceived risk. This done using loans scoring system, external information providers, risks selfassessment for SME owners. Lastly reducing cost of granting loans through applying latest information technologies streaming following UNCTAD report 2001.

Secondly, best practices implement by USA to improve domestic loans contribution to GDP are:Internet association Washington DC(2015) revealed that internet industry in the past years have been contributing to real GDP in an exponential rate in USA. Michael Beckerman president and CEO of the Internet Association in 2014 said" internet sector have doubled contributing to real GDP, that is increased by more than two-fold and employees' wages far exceed the national average". From this large contribution for example in 2014, internet contributed 6\% of real GDP, again from 2007 to 2012 the internet increased nominal value by approximately $110.4 \%$. US government therefore is increasing money allocated on the internet industry and financial institutions are equally increasing their domestic loans to internet sector than construction, computer, electronic product, broadcasting, and telecommunication.

Baldrige Economic Impact (2020) reported on this article that USA have been using another best practice called "Malcolm Baldrige National Quality Award for excellence granted by the president of USA and it objective was to generate $1 \mathrm{~b}$ dollar per year by public-private partnership .This strategy helps to motivate and increase competition among manufacturing industries, hence improving loans granted and GDP.

Park .H, Kim JD (2020) proposed to US government in an article Asian journal of sustainable and social responsibility that there should be transition toward green banking by financial regulators and financial institutions to improve loans and GDP.

Thirdly, some of the best practices in Africa to improve domestic loans contribution to GDP are as follows reported by some articles:

IMF report (2016) revealed the following as best strategies implemented in Africa. To provide a strong legal and institutional framework, not keeping aside good corporate governance.

Fortify supervision, continental monitoring and consolidating basis, since re-enforcement mechanism on prudential ratios remains weak in some African countries. Equally creation and expansion of panAfrican banks like Eco -bank. 
Implementing a comfortable regulatory environment to enlarge financial institution role. For example introduction of mobile banking, low cost of transaction and technological innovation.

$\mathrm{UNCTAD}(2007)$ report revealed that African countries should promote productive investment when loans are taken instead of financing war or doing consumption. That is promoting reproductive debt and discouraging dead weigh debt. Again in that report UN, encourages financial institutions in Africa to accept remittances and discourages capital flight, for example creating diaspora's bonds (foreign bond), reducing cost of remittances.

Economic report banking in Africa (2018) revealed that countries in Africa should support financial stability and delivering on financial inclusion. More so in that article it revealed that African government should reduce crowding out in order not to affect loans given to Private sector in Africa as a continent.

\section{Methodology}

The research designed is quantitative longitudinal research, which is time-series experimentally assigned. This research covers a period of 30years, from 1990 to 2019. Under these 30 years, data obtained for two variables, which are domestic credit provided by commercial banks and other microfinance in the economy and GDP. These data are collected using secondary source. Data comes from published statistics from books and World Bank (specifically database of WDI), IMF, government documents having data from different financial institutions in Cameroon. These data are used for testing of the hypothesis.

Data used in writing this research were past records published by international institutions like world bank, IMF, IDA. Instruments like data base (WDI database2020) was used to collect data of dependent and independent variables. Apart from this, since the research is quantitative, tools like experimental approach and observation was equally considered.

More so, the simple regression model will be solved using SPSS (Statistical Package for the social science) which permit the treatment of data collected without using calculation formulae. Results like mean, coefficient of correlation, standard deviation, distribution of variables indicating the trend will be processed by SPSS.

This study is expected to measure or assess the extent at which domestic credit given by financial institutions can bring economic growth in Cameroon" ceteris paribus" (meaning considering that other factors are held constant. Data collected from the world Development Indicator (WDI) data base which was provided by the world bank, researcher sample of data covered 30 years period from 19902019. Following that the research is quantitative, the time-series method was used to obtain the data from the world bank. Time considered in the database was 30 years, country Cameroon and three series that were GDP (billion US dollars), Real GDP growth (\%) and domestic credit provided by financial sector (\% GDP).

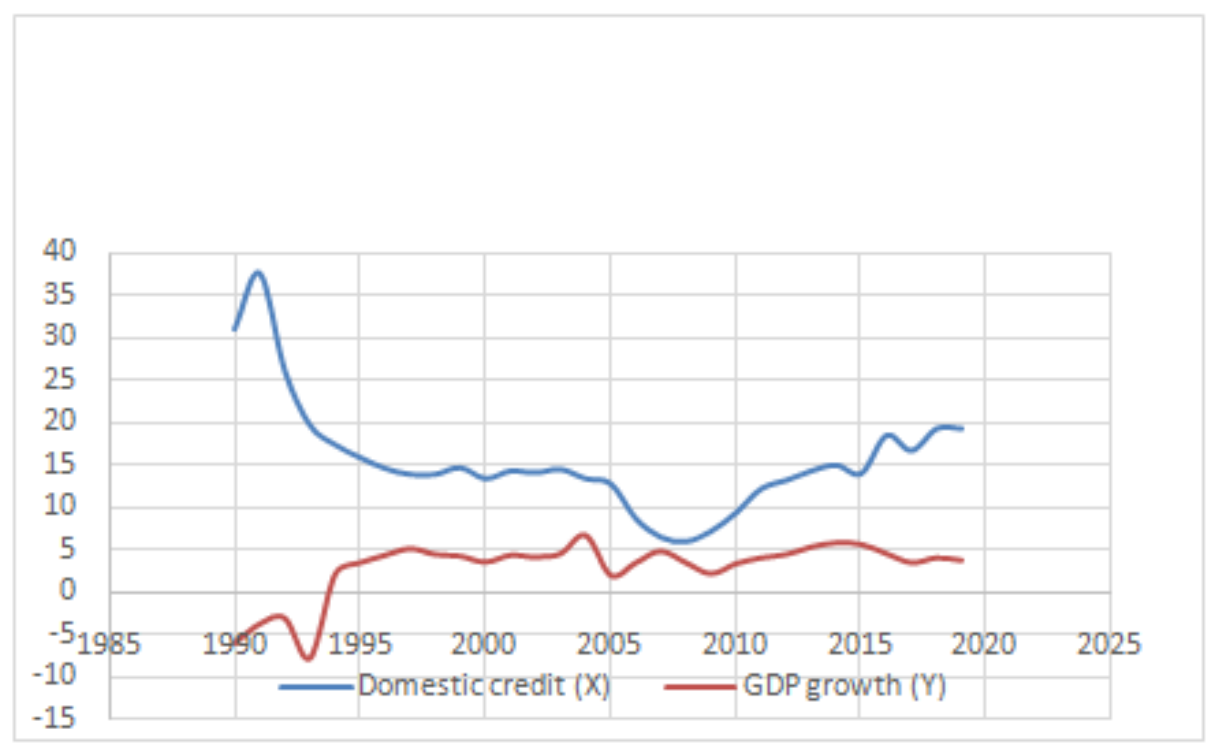

Figure2. Trend of real GDP growth and Domestic credit rate over 30years period from 1990-2019. 
From the graph above X-axis represent time from 1990-2019 and Y-axis represent both domestic credit rate and real GDP rate. Detail explanation of the trends will be given in chapter 4 (that is result and discussion)

The research involves the use of simple linear regression analysis as a method of analysing the data collected. That is a model with one dependent variable and one independent variable is a simple linear regression. This choice of analysis has two reasons; firstly, it helps develop a regression model that demonstrates the amount of domestic credit given to the economy by financial institutions to changes in GDP. Secondly, the regression model is essential because it enables the research to measure the extent of correlation between domestic credit and GDP.

Besides, the research entails the use of a descriptive method of data analysis to supplement the linear regression analysis. These descriptive methods of data analysis include mean, standard deviation, variance, observation, maximum, minimum, skewness, kurtosis and coefficient of correlation.

The simple regression model is most appropriate for the researcher to establish the relationship between domestic credit and the growth of the GDP. This model has two variables which is given as;

$\mathrm{Y}=\beta f(\mathrm{~d})+\dot{\varepsilon}$

Where $\mathrm{Y}=\mathrm{GDP}$ and $\mathrm{d}=$ Domestic credit provided by financial institutions in Cameroon

The equation above assumes a linear relationship between $\mathrm{Y}$ and $\mathrm{d}$. The symbol Brepresent coefficient of correlation, $\dot{\varepsilon}$ represent other factors of economic growth and $f(\mathrm{~d})$ function of domestic credit. This model has mainly two variables that is the dependent variable and the independent variable whose data are given on the table above. GDP (Y) is the dependent variable and domestic loan (d) is the independent variable.

The hypothesis to be tested if other factors are held constant, the Central African Banking Commission (COBAC) regulates activities of financial institutions and the level of interest rate, such loans are collected can increase investment and bring economic growth. However, other factors like highlabourforce, high technological, low interest rate on loans, high level of investment, low embezzlement and corruption, political stability can also bring a change in economic growth of Cameroon as other future researchers will tests.

\section{RESUlts AND DisCUSSION}

This chapter involves time series data collected, evolution of real GDP rate and domestic credit rate indicating trends, data analysis (descriptive statistics and Pearson correlation analysis), testing of hypothesis using Pearson correlation coefficient and discussion of results with articles supporting results obtained .Data was collected on two variables which are domestic loans (credit) and GDP. Independent variable which is domestic loans and dependent variable is GDP for a period of 30years (1990-2019).

Table2.0. Time series data collected from 1990-2019

\begin{tabular}{|l|l|l|l|}
\hline Year & Current GDP (billionUSD) & Real GDP rate (\%) & Domestic Credit providedby financial sector(\%GDP) \\
\hline 1990 & $11,151,578,050$ & -6.1 & 30.9 \\
1991 & $12,434,370,005$ & -3.8 & 37.5 \\
1992 & $11,396,310,990$ & -3.1 & 26 \\
1993 & $15,498,179,313$ & -7.9 & 19.6 \\
1994 & $10,600,157,683$ & 2.1 & 17.3 \\
1995 & $9,643,953,174,8$ & 3.5 & 15.8 \\
1996 & $10,513,387,441$ & 44 & 14.5 \\
1997 & $10.833,497,457$ & 5.2 & 13.8 \\
1998 & $10,612,847,429$ & 4.5 & 13.8 \\
1999 & $11,198,378,749$ & 4.3 & 14.6 \\
2000 & $10,083,937,740$ & 3.6 & 13.3 \\
2001 & $10,371,327,756$ & 4.4 & 14.2 \\
2002 & $11,579,343,088$ & 4.2 & 14.0 \\
2003 & $14,548,845,764$ & 4.6 & 14.4 \\
2004 & $17,430,933,517$ & 6.8 & 13.3 \\
2005 & $17,944,084,201$ & 2.0 & 12.7 \\
2006 & $19,356,046,327$ & 3.5 & 8.6 \\
\hline
\end{tabular}




\begin{tabular}{|l|l|l|l|}
\hline 2007 & $22,365,265,025$ & 4.9 & 6.4 \\
2008 & $26,409,781,215$ & 3.5 & 5.9 \\
2009 & $26,017,925,551$ & 2.2 & 7.1 \\
2010 & $26,143,818,509$ & 3.4 & 9.3 \\
2011 & $29,337,006,833$ & 4.1 & 12.1 \\
2012 & $29,104,437,355$ & 4.5 & 13.1 \\
2013 & $32,348,149,947$ & 5.4 & 14.2 \\
2014 & $34,942,948,737$ & 5.9 & 14.9 \\
2015 & $30,916,218,544$ & 5.7 & 13.9 \\
2016 & $32,621,535,418$ & 4.6 & 18.4 \\
2017 & $34,922,782,310$ & 3.5 & 16.6 \\
2018 & $38,675,205,293$ & 4.1 & 19.2 \\
2019 & $38,632,000000$ & 3.9 & 19.2 \\
\hline
\end{tabular}

Source: World Development Indicator (World bank database2020) www.data.worldbank.org

The time series data collected is used to transform the table into a graph showing the trend of real GDP growth in percentage and domestic loans growth rate from 1990-2019, that is 30years period. In the process of collecting the time series; time, GDP in nominal terms (busd), real GDP in percentage and domestic loans rate (\%). Table 3 represent just a cross section of table 2 to come out with graph showing trends of two variables used in the simple linear regression model of the researcher as follows:

Table3. Evolution of real GDP rate (\%) and domestic credit rate (\%)

\begin{tabular}{|l|l|l|}
\hline Year & Domestic Credit provided by financial sector (GDP) & Real GDP rate (\%) \\
\hline 1990 & 30.9 & -6.1 \\
1991 & 37.5 & -3.8 \\
1992 & 26 & -3.1 \\
1993 & 19.6 & -7.9 \\
1994 & 17.3 & 2.1 \\
1995 & 15.8 & 3.5 \\
1996 & 14.5 & 44 \\
1997 & 13.8 & 5.2 \\
1998 & 13.8 & 4.5 \\
1999 & 14.6 & 4.3 \\
2000 & 13.3 & 3.6 \\
2001 & 14.2 & 4.4 \\
2002 & 14.0 & 4.2 \\
2003 & 14.4 & 4.6 \\
2004 & 13.3 & 6.8 \\
2005 & 12.7 & 2.0 \\
2006 & 8.6 & 3.5 \\
2007 & 6.4 & 4.9 \\
2008 & 5.9 & 3.5 \\
2009 & 7.1 & 2.2 \\
2010 & 9.3 & 3.4 \\
2011 & 12.1 & 4.1 \\
2012 & 13.1 & 4.5 \\
2013 & 14.2 & 5.4 \\
2014 & 14.9 & 5.9 \\
2015 & 13.9 & 5.7 \\
2016 & 18.4 & 4.6 \\
2017 & 16.6 & 3.5 \\
2018 & 19.2 & 4.1 \\
2019 & 19.2 & 3.9 \\
\hline
\end{tabular}

Source: Worldbank database 2020

From the table given, which depict a cross section of time -series data collected to illustrate a graph showing the trends and type of correlation existing between domestic credit growth rate and real GDP rate. Time from 1990-2019 is horizontally graduated as X-axis while Y-axis which is vertical graduated considering both domestic credits rate (\%) and real GDP growth rate (\%). Treating these two series and 30years time data, the researcher obtained the line graph and other extensive diagram like scatter plot as follows. 


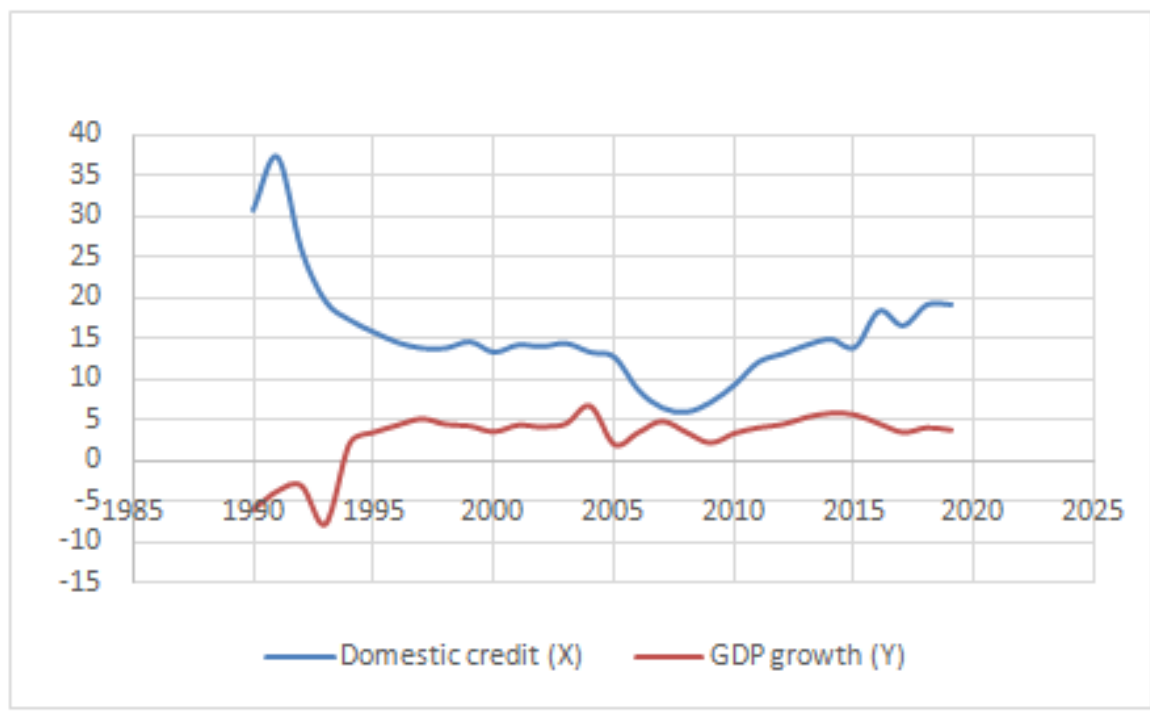

Figure3. Graph indicating trends of real GDP rate (\%) and domestic credit (\%)

Following data from the World Bank database (WDI 2020 database), financial institutions trends for credit(loans) from 1990-2019 indicate a fluctuation of domestic credit rate. Meaning progression and regression within 30years. (fig2)

The trends indicate that from 1990-1992, there was a rapid increase from $30.9 \%$ to $37.5 \%$ due to the economic crisis that took place in Cameroon around the late 1980s. So the period from 1990-1994 financial institutions needed many loans since many borrowers needed enough money because of the economic depression.

After the 1994 devaluation of FCFA to correct the persistence balance of payment deficit and brought back Cameroon to the period of recovery. From 1992-1996, the domestic credit rate given by financial institutions experienced a regression from $37.5 \%$ to $14.5 \%$. From 1996-2005, domestic credit was slightly stable. But from 2005-2010 due to the global financial crisis in 2008, the domestic credit rate fell rapidly from $12.7 \%$ to $7.1 \%$. Again from 2010-2019, the domestic credit rate given by financial institutions in Cameroon had been experiencing an increase from $7.1 \%$ to $19.2 \%$ because of the political crisis (Anglophone crisis) that started in 2016 up to 2020.

The major issues or problems financial institutions are facing or had faced from 1990-2019 are the economic crisis of the late 1980s and effects felt from 1990-1994, the world financial crisis of 2008, the political crisis of 2016-2020, and high-interest rate levied on loans that are not even reproductive but for consumption and finance of war (deadweight debt). In all these statements of problems can affect domestic credit and GDP (economic growth) of Cameroon. To back up the reliability of my observation about trends of domestic credit from 1990-2019, you can check: WDI database 2020, Investment climate statement of Cameroon(2020) report, 2019 investment climate statement of Cameroon, www.the globaleconomy.com, Cameroon report, Cameroon economic update, world bank group(2014), Cameroon fourth review under the extended credit facility(2019), Cameroon fifth review under the extended credit facility(2020).

On the otherhand, still on the same graphreal GDP rate also experience a fluctuation between 19902020.That is an increased and decreased within 30years period.From 1990, real GDP rate was $-6.1 \%$ because of the impacts of economic crisis of 1980's. So from 1990-1992, Cameroon experienced period of recovery, even the increased in loans collected during that period was for consumption and not investment.

In 1993 Cameroon real GDP was at lowest level, that is $-7.9 \%$ reason why measures like devaluation of FCFA in 1994 was introduced by IMF to solve the persistent balance of payment deficit and takeout Cameroon from the period of depression. After experiencing a period of recovery from 19931997 where real GDP increased from $-7.9 \%$ to $5.2 \%$, there was a steady fluctuation from 1997-2003.

In 2004, Cameroon recorded the highest real GDP of $6.8 \%$ during the period of boom. However, from 2004-2006 there was a decreased because Cameroon was accepted into HIPC. Apart from that 20072010 recorded a regression from $4.9 \%$ to $3.4 \%$ caused by the world financial crisis of 2008. 
Again, what is special about the period from 2005 to 2010 is that as domestic credit rate decreases, real GDP rate increases thereby closing the gap existing between these two variables. Some of the factors that could account for this may be that the business climate was peaceful, low taxes, investment was profitable though a period of world financial crisis, loans were reproductive since there was no war during that period in Cameroon and government subsidizing investors during that period.

From 2010-2016 Cameroon recorded a slight increase in real GDP. Unfortunately, the advent of the political crisis (Anglophone crisis) from 2016 to present date had brought a decreased in real GDP from $4.6 \%$ to $3.9 \%$ recorded for 2016 and 2019, respectively. To back up reliability of my observation concerning the fluctuation in real GDP within 1990-2019 you can check or read: WDI database 2020, Cameroon economic update (2014), Cameroon international monetary fund report (2019), Cameroon real GDP growth (1980-2019) knoema.com, Political economy of Cameroon's post-independence growth, World bank document (1990-2019), Cameroon economic outlook/African development bank report 2019, World economic situation and prospect(2018), just to name a few.

All in all based on correlation analysis from these two mentioned curves in Fig 2, there is a correlation between domestic loans curve and real GDP curve but a negative moderate relationship between domestic loans and real GDP.

\subsection{Data Analysis}

Using two series and 30years time, the researcher formulated a simple regression model with one independent variable which is domestic credit (d) and one dependent variable which is GDP(Y). The regression model is given as:

$\mathrm{Y}=\beta f(\mathrm{~d})+\dot{\varepsilon}$

To solve the simple regression, model the researcher used SPSS (Statistical Package for Social Science), which permit the treatment of time -series data. Considering two series data which are domestic credit growth rate, real GDP growth rate and time $(\mathrm{N})$ which is 30years. Combining the possibilities, statistical processing facilities provided by the software programs and not using calculation formulae, the following descriptive statistical analysis were obtained in table 4 . That is mean, standard deviation, median, variance, observation, skewness, maximum, minimum and kurtosis were obtained providing general statistics of the regression equation.

Table4.0. Descriptive Statistical Analysis of real GDP and Domestic credit (1)

\begin{tabular}{|l|l|l|l|l|l|l|}
\hline & $\mathrm{N}$ & Minimum & Maximum & Mean & Std. Deviation & Variance \\
\cline { 2 - 7 } & Statistic & Statistic & Statistic & Statistic & Statistic & Statistic \\
\hline REAL GDP GROWTH(\%) & 30 & -7.9000 & 6.8000 & 2.926667 & 3.4886944 & 12.171 \\
\hline $\begin{array}{l}\text { DOMESTIC CREDIT } \\
\text { PROVIDED BY }\end{array}$ & 5.9000 & 37.5000 & 15.486667 & 6.6236636 & 43.873 \\
FINANCIAL SECTOR & & & & & & \\
\hline \begin{tabular}{l} 
Valid N (listwise) \\
\hline
\end{tabular} & 30 & & & & & \\
\hline
\end{tabular}

Overall explanation is that from the observation of 30 years, real GDP minimum statistics was $-7.9 \%$ and maximum recorded was $6.8 \%$ with a mean, Standard deviation and variance of 2.9, 3.4 and 12.17 respectively.

On the other hand, still from the observation of 30 years, domestic credit minimum statistic was $5.9 \%$ and maximum recorded was $37.5 \%$ with a mean, standard deviation, and variance of $15.4,6.6$, and 43.8 respectively.

Table5.0. Descriptive Statistical Analysis of real GDP and domestic credit (2)

\begin{tabular}{|c|c|c|c|c|}
\hline & \multicolumn{2}{|c|}{ Skewness } & \multicolumn{2}{|l|}{ Kurtosis } \\
\hline & Statistic & Std. Error & Statistic & Std. Error \\
\hline REAL GDP GROWTH (\%) & -2.050 & .427 & 3.603 & .833 \\
\hline $\begin{array}{l}\text { DOMESTIC CREDIT PROVIDED } \\
\text { FINANCIAL SECTOR }(\%)\end{array}$ & 1.626 & .427 & 3.901 & .833 \\
\hline Valid N (listwise) & & & & \\
\hline
\end{tabular}

Table 5 still indicate descriptive statistical analysis for both dependent and independent variables. Considering the fact that components of central tendency mean, median and mode can be illustrated in 
a normal distribution, the result in table 5 can be used. Real GDP in term of skewness recorded -2.05 with standard deviation error of 0.4, Domestic credit rate recorded 1.6 with std error of 0.4. On the other hand, kurtosis that measures the shape of a distribution, 3.6 and 3.9 for real GDP and Domestic loans respectively.

Table 6. Pearson Corrélations coefficient Analysis

\begin{tabular}{|c|c|c|c|c|}
\hline & $\begin{array}{l}\text { REAL GDF } \\
\text { GROWTH }(\%)\end{array}$ & $\begin{array}{l}\text { DOMESTIC } \\
\text { PROVIDED } \\
\text { SECTOR }\end{array}$ & BY & $\begin{array}{r}\text { CREDIT } \\
\text { FINANCIAL }\end{array}$ \\
\hline REAL GDP GROWTH (\%) Pearson Corrélation & 1 & $-.667^{* *}$ & & \\
\hline CREDIT Sig. (2-tailed) & & .000 & & \\
\hline $\begin{array}{ll}\text { PROVIDED } & \text { BY } \\
\text { FINANCIALSECTOR }(\%)\end{array}$ & 30 & 30 & & \\
\hline $\begin{array}{|ll|}\text { DOMESTIC } & \text { CREDITPearson Correlation }\end{array}$ & $-.667^{* \pi / 2}$ & 1 & & \\
\hline PROVIDED BY FINANCIALSig. (2-tailed) & .000 & & & \\
\hline SECTOR & 30 & 30 & & \\
\hline
\end{tabular}

**. Correlation is significant at the 0.01 level (2-tailed).

Source: SPSS output

To know the level of relationship between dependent and independent variables, Pearson correlation analysis can be used. Table 6 consist of correlation matrix in which figures are distributed symmetrically on both sides of the diagonal correlation coefficient equal 1. Also on table 6 we have values of materiality (sig) and number of observation $(\mathrm{N})$ which is 30 .

When correlation coefficient is $(+1)$, it means perfect direct correlation between variables, if it's $(-1)$ indicate perfect negative relation and when it's 0 indicate no correlation.

Testing the correlation between variables of this work gave (-0.67), which implies negative correlation between domestic loans and real GDP

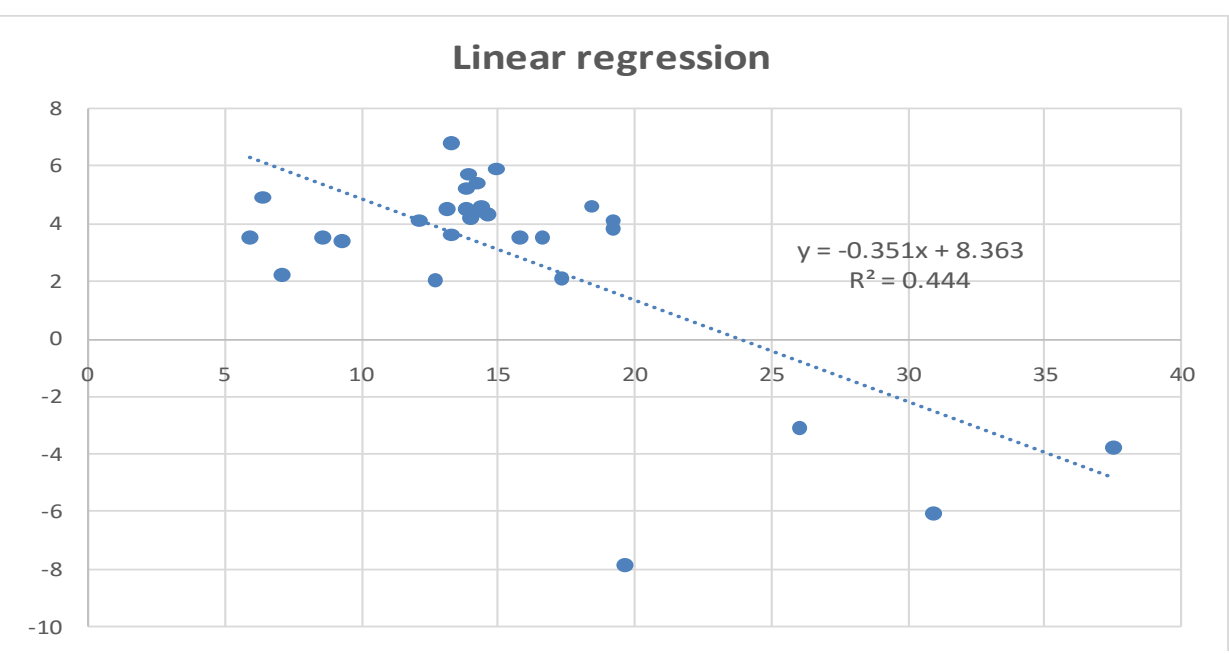

Figure4.0. Scatter plot diagram using domestic loans rate (\%) and real GDP(\%) for a linear regression within 30years

\subsection{Hypothesis Testing and Discussion Using Pearson Correlation Coefficient}

Hypothesis testing using coefficient of correlation(r) is -0.67 since $r$ is negative, therefore the null hypothesis (H0) is rejected which state that there is a significant relationship exist between domestic loans and GDP. This is because from the results provided by SPSS, rindicates that there is a correlation, but negative moderate relationship between domestic loans and GDP. In all we can say that there existsa significant relationship between domestic loans provided by financial institutions and GDP (economic growth).

Given that Pearson coefficient of correlation is -0.67 and following the decision rule that the null hypothesis is rejected, it implies that there is an inverse relationship between domestic loans provided by financial institutions and GDP. Meaning as GDP decreases, economic agents or borrowers increases their demand for domestic loans. 
Furthermore, this implies that about $-67 \%$ of changes in the level of GDP are explained by changes in the amount of domestic loans. Meaning the simple regression function fit that data by $-67 \%$ and the remaining 33\% that can move the correlation to become positive can be accounted by other factors influencing economic growth like high technology, training of workers, political stability, high working population, low interest rate just to name a few.

Given that the decision rule is rejecting the null hypothesis because the research results show negative correlation, the results of this work can therefore be supported by other related researchers or articles that had negative correlation between domestic loans and GDP as follows.

BarisAltayligil (2013) article, whose objective of the study was to investigate the relationship between domestic public debt and financial development in Turkey economy between 2002-2012. Though the researchers work had two data studies, one of the developing countries studies proposed two approaches. Using time series analysis, part of the results indicated a negative relationship between domestic loans and financial development. Using multiple regression analysis, variables considered were domestic debt/GDP ratio and principal financial indicators like turnover ratio, interest rate margin and inflation. Similar to this research study, Baris work is time series where in the results show negative correlation, share similar issue like crisis, and used linear regression analysis. However, different because he used multiple regression model.

Henri Njangang (2018) investigated the empirical effect existing between public debt on economic growth, using a sample of six CEMAC countries from 2000 to 2016.The results came out negative relation and statistically significant effect. Though using public debt and economic growth as variables, it is related to my work because the research design is time series, results are negative and Henri's case study is CEMAC of which Cameroon is member and share similar statement of problem like crisis.

RabiaAtique (2012) article on impacts of domestic and external debt on the economic growth, took Pakistan as case study from 1980 to 2010 using Ordinary Least Square (OLS) to co-integration, serial correlation testing, in order to verify heteroscedasticity. The results for the research work came out negative relationship between domestic debt and economic growth. Equally results indicating the relationship between external debt and economic growth came out negative. The result ended by re iterating that external debt is a stronger factor that slows down economic growth within that period of research. This come to support my work because Rabia also used time series, results were negative and share similar variables, though different methods of testing.

EkayanaNurnaningtyas (2018) journal on effect of gross domestic product, inflation, interest rate, profitability and capital adequacy ratio to non-performing loans on mixed banks and data collected between the period 2012-2015. Using linear multiple regression analysis, results for the work came out negative, after using t-test and correlation analysis. Based on results of hypothesis testing, the negative relationship implies that the increase in GDP will decrease non-performing loans of the bank. It supports my findings because results were negative, share similar variables, used regression analysis and SPSS to obtain output.

Discussion about this work can further be supported and presented on tables indicating findings of each research problem as follows:

\subsection{Trends of Dependent and Independent Variables}

Table7.0. Trends of dependent and independent variables

\begin{tabular}{|l|l|l|}
\hline Trends & Authors or Researchers & Discussion \\
\hline 1 & Henri Njangang(2012) & Fluctuation between 2000-2016 \\
\hline 2 & George Kobo, DNjinkeu, BP Fosso & Fluctuation after post independent \\
\hline 3 & Cameroon IMF report 2019 & Fluctuation among variables \\
\hline 4 & Knoema.com & Fluctuation between 1980-2019 \\
\hline
\end{tabular}

Following the above mentioned four researchers and articles, despite their different time considered, trends existing between variables are fluctuating. It supports this work because the time considered is between 1990-2019, also share similar variables and indicate fluctuation between dependent and independent variables

\subsection{Issues or Factors Contributing to Negative Correlation}


Table8.0. Issues or factors contributing to negative correlation

\begin{tabular}{|c|c|c|}
\hline Issues or Problems & Authors or documents & Discussions \\
\hline Economic crisis (1980) & Mbu Daniel Tambi (2015) & $\begin{array}{l}\text { The aim of the work was to } \\
\text { indicate howeconomic growth was } \\
\text { affected negatively due to } \\
\text { economic crisis. Therefore, in } \\
\text { thatArticle of industrial distribution } \\
\text { and business 6(1) vol } 6 \text { explained } \\
\text { the aftermath. Effects Cameroon } \\
\text { faced because of crisis. }\end{array}$ \\
\hline Financial Crisis (2008) & $\begin{array}{l}\text { Sebastian, et.al. / UNCTADS/ } \\
\text { GDS/ MDP/ } 2010\end{array}$ & $\begin{array}{l}\text { The documents show financial and } \\
\text { economic crisis of 2008-2009 } \\
\text { negative effects, how it affects } \\
\text { economic growth of developing } \\
\text { countries which Cameron was not } \\
\text { left-out }\end{array}$ \\
\hline $\begin{array}{l}\text { Political Crisis } \quad \text { (Anglophone } \\
\text { Crisis) }\end{array}$ & BTI 2020 Cameroon country report & $\begin{array}{l}\text { BTI } 2020 \text { Cameroon country report } \\
\text { indicate how different sectors or } \\
\text { activities are affected since } \\
\text { Anglophone crisis began in } 2016 \text {. } \\
\text { All these contribute to negative } \\
\text { correlation between domestic loans } \\
\text { and GDP as tested by the } \\
\text { researchers work. }\end{array}$ \\
\hline COVID-19 (2019) & SoppoNtoubaRegine (2020) & $\begin{array}{l}\text { This work indicates the economic } \\
\text { impacts of COVID_19 in } \\
\text { Cameroon. After referring to many } \\
\text { sectors affected negatively because } \\
\text { of COVID-19. The article } \\
\text { concluded that this pandemic } \\
\text { situation slows down the economic } \\
\text { growth by 0.5\%, hence it supports } \\
\text { the researchers work. }\end{array}$ \\
\hline
\end{tabular}

\subsection{Cameroon Government Programs to Improve the role of Domestic Loans to Economic} Growth

There are several programs that can be utilized to improve the role of Domestic loans in economic growth. First is the support for financial stability by avoiding unnecessary crisis, introduce deferral tax, social security payment, low interest on loans during period of crisis. These strategies are implemented by many African countries and has gone a long way to improve role of domestic loans on economic growth. This can be further supported by the following articles and report, that is economic report banking in Africa (2018), UNCTAD (2007).

Secondly, implement structural policies to help SME's, adopt digitalized working methods to find new markets and increase GDP even during confinement. To support this program, Ireland and United Kingdombanks implemented this strategy and was successful. Details can be verified in an article improving the competitiveness of SME's in developing countries. Also in another document UNCTAD/SDTE/misc.48 (2001)

Third, Cameroon government should set up National Quality Award for Excellence given by the president to raise GDP and strengthen competition among firms, leading to positive correlation among variables. This type of program was implemented in USA and Successful. The strategy was called the Malcolm Baldrige National award for excellence where it was given by the president of USA. The effects wasthat, it increases 1billion usd annually by public - private partnership, helps to motivate and augment competition among manufacturing industries, hence improving loans given and GDP. (Baldrige economic impact 2020).

Lastly, Government and financial institutions should advice loan borrowers to use the money on profitable investment and not loans to finance war or consumptions. This strategy is supported by Unctad(2007) it can help to foster economic growth, it common in war countries like Nigeria during Boko- haram, Iran , Sudan just to name a few. 


\section{CONCLUSION}

Base on the findings of this study, the following conclusions are drawn:

1. The effects of the fluctuation between domestic loans and GDP are, Cameroonians from 19902019 cannot have a fixed plan of their budget, fluctuation in standard of living, has created a business cycle full with fluctuations and death cases has increased because of poverty due to crisis.

2. The statistical findings of correlation coefficient are -0.67 indicating negative correlation between dependent and independent variables. The relation is inverse because of the loans not directed into profitable investment but financing war, again because of political instability that reduces size of the market, hence GDP

3. MY realization about the contribution to economic growth is that Cameroon government should avoid unnecessary war, bring financial stability, financialinstitutions should reduce interest rate during period of war and encourage investors to bring about economic growth.

4. Therefore, there is a need for the government and lending investors to formulate program and policies that heightened the contribution of Domestic loans to economic growth.

\section{RECOMMENDATIONS}

After undergoing the research on the role of domestic loans given by financial institutions on economic growth, since results were negative correlation, the researcher can then make the following recommendations that can improve the correlation to become positive in future.

Firstly, to solve the problem of financial instability, that is fluctuation in trends within 1990 to 2019 , government need to support financial stability by avoiding unnecessary crisis, introduce deferral of tax, social security payment, low interest rate on loans during period of crisis.

Secondly, Cameroon government should put in place structural policies to help small and medium size enterprises (SME's) adopt a digitalized working method, in order to find new markets and increase GDP even during crisis or confinement.

Thirdly, Cameroon government should set up "National Quality Award for excellence (NQA) given by the president and it objectives will be to generate atleast 1billion dollar a year by public -private partnership. This government program will help to motivate and increase competition among manufacturing industries, hence improving loans granted and GDP.

Fourthly, government and financial institutions should advice loans borrowers to use the money on profitable investments in order to easily payback the loan and not using these loans to finance war or consumption (deadweight debt).

All in all, if Cameroon government work in collaboration with, COBAC, financial institutions, investors and customers of these financial institutions to implement these mentioned recommendations, domestic loans can become positively correlated to GDP as future researchers will test.

Considering the fact that this work focused on the role of domestic loans on economic growth in Cameroon, a further research can be conducted on assessing the role of domestic loans given by micro financial institutions (MFI) on economic growth in Cameroon. Equally, other future researchers can write on this same topic but using both coefficient of correlation and T-testing as methods of assessing role of domestic loans on GDP.

\section{REFERENCES}

[1] Cynthia, N. (2008). Assessing the role of a micro-financial institution on economic growth in Cameroon. In the University of Buea (Vol. 56, Issue 3). https://doi.org/10.1525/sp.2009.56.3.385

[2] Hans, J. (1980). Economic and Commercial dictionary.

[3] Ikome, M. N. (2011). Assessing the role of commercial banks and economic growth in Cameroon. The University of Buea.

[4] IMF. (2018). IMF Annual Report, October 2018. 1-108. https://www.imf.org/external/pubs/ft/ar/2018/ eng/assets/pdf/imf-annual-report-2018.pdf 
[5] International Monetary Fund. (2009). Cameroon: Financial System Stability Assessment: Update. IMF Staff Country Reports, 10(09/51), 54. https://doi.org/10.5089/9781455204878.002

[6] John, M. K. (1936). macro-economics. The Economic Journal, 87(346), 335. https://doi.org/10.2307/223 2096

[7] Lynch, D. (1996). Study of Selected Asia-Pacific Countries. The Developing Economies, 1(March).

[8] Ray et al. (1994). principles of Macro-Economic (6th ed.). Addison Wesley Education publisher.

[9] Romer, P. (2018). Encyclopedia of Economics.

[10] Simion, D., Stanciu, M., \& Armăşelu, S. (2015). Correlation Analysis Between Structure Financial System and Economic Growth in Romania. Procedia Economics and Finance, 32(15), 1332-1341. https://doi.org/10.1016/s2212-5671(15)01510-5

\section{BOOKS SOURCE}

- Wemnje, C. (2016). New Approach to Ordinary Level Economics.

- UNCTAD Economic development in Africa

- Akuntansi (2018), vol 14 Equilibrium, journal Ekonomi-management

- World applied sciences, Journal 20(1) 120-129 , 2012

- Asian research journal of art and social sciences(2018), vol 5

- 10.9734/ARJASS/2018/39080

- October (2018) journal of international business and economics 18(3) 29-38

- December 2015 contemporary Arab Affairs 9(1), 1-5

- International Journal of Economics(2013) Vol 5

- $\quad$ Economic report banking in Africa 2018

- International Monetary Fund report 2016

- UN.CTAD/ITE/TEB/Misc-2001

- Asian journal of sustainable and social Responsibity. Article number 5(2020)

- Internet Association, Washington DC(2015)

ELECTRONIC SOURCE:

CICLO ESCULTÓRICO TORREPAREDONES - Apps on Google Play.

https://play.google.com/store/apps/details?id=com.CETEMET.baena\&hl=en_US

http://www.internetaassociation.org

http://www.baldriquefoundation.org

https://doi.org/10.1186/341180-020-00034-3

http://www.europa.eu

https://www.moodysanalytics.com

https://www.elibrary.imf.org

WwW.imf.org

Government Entrepreneurship Development Programshttps://www.ijaar.org/articles/Volume4Number4/Social-Management-Sciences/ijaar-sms-v4n4-apr18-p27.pdf

Cameroon economic update, world bank group (2014)

www.worldbank.org, Africa ,Cameroon report

www.theglobaleconomy.com Cameroon

Investment climate statement of Cameroon (2020) 
www.state.gov report of Cameroon.org

Cameroon economic outlook/African development bank report 2019

www.afdb.org

World economic situation and prospect(2018) www.un.org

World bank document 1990-2019, (www.documents.vse mirnyjbank.org)

Cameroon real GDP growth 1980-2019 (knoema.com)

Cameroon international fund report(2019) www.imf.org

George Kobou, D Njinkeu and BP Fosso, Political economy of Cameroon's post-independence growth, www.swarthmore.edu

Document for growth strategy and employment(2014)Vol 7 www.world bank.org Africa, Cameroon report

Economic AnalysisOfthe Jamaican Economy Economics Essay.

https://www.ukessays.com/essays/economics/economic-analysis-of-the-jamaican-economyeconomics-essay.php

Bank loan and Credit Collection in Nigeria- Gross Archive.

https://www.grossarchive.com/project/3446/BANK-LOAN-AND-CREDIT-COLLECTION-IN-

NIGERIA.html

Chapter 2 The Environment of Business.

https://1939095516.rsc.cdn77.org/SITE/ALL/PDF/C9780134302072TB.pdf

What are someNorms\& Values in France?|Yahoo Answers.

https://uk.answers.yahoo.com/question/index?qid=20090821160715AAxR5HG

Isaksson, Mats, et al. "Modelling the Effective Dose to a Population fromFalloutafter a Nuclear Power Plant Accident-A Scenario-BasedStudy with Mitigating Actions." PLoS One, vol. 14, no. 4, Public Library of Science, Apr. 2019, p. e0215081.

EconomicGrowth and Development of Nigeria Economics Essay.

https://www.ukessays.com/essays/economics/economic-growth-and-development-of-nigeriaeconomics-essay.php

GovernmentEntrepreneurshipDevelopmentProgrammes

https://www.ijaar.org/articles/Volume4-Number4/Social-Management-Sciences/ijaar-sms-v4n4apr18-p27.pdf

Correlationanalysisbetween structure financial system and economicgrowth in Romania Dalia Simiona, *, MarietaStanciua , 6DELQ\$UPăúHOXa a University of Craiova, Faculty of Economics and Business Administration, Str. A.I.Cuza, no. 13, Craiova, Dolj

Citation: Dr. Kristine Joy S. Simpao, Kum Raphael Tegha, "An Assessing the Role of Domestic Loans on Economic Growth in Cameroon" International Journal of Managerial Studies and Research (IJMSR), vol 9, no. 4, 2021, pp. 137-158. doi: https://doi.org/10.20431/2349-0349.0904012.

Copyright: () 2021 Authors. This is an open-access article distributed under the terms of the Creative Commons Attribution License, which permits unrestricted use, distribution, and reproduction in any medium, provided the original author and source are credited. 